Theological Research • volume $8(2020)$ ・ P. 59-68

doi: https://doi.org/IO.15633/thr.4I28

Olli-Pekka Vainio

https://orcid.org/0000-0001-8823-2356

University of Helsinki

\title{
Christ's Real Presence in the Eucharist and Relational Ontology
}

\section{Abstract}

This paper argues for an interpretation of the real of presence of Christ in the Eucharist using relational ontology as the basic metaphysical theory. Relational ontology, in its one form, denies the existence of intrinsic properties so that things that exists are just instantiations of particular sets of properties that receive their essence from their relation to other things. If there are good reasons to accept relational ontology, it could potentially help one to solve certain problems in transubstantiation model, without giving up the idea of real presence.

KeYWORDS

Eucharist, real presence, Lutheranism, Catholicism, relational ontology 


\section{INTRODUCTION}

What do we mean when we speak about Christ being "really present" in the Eucharist? In this essay, I will propose a view of real presence that is able to subscribe to the idea of real presence by fulfilling the desiderata laid out by Elisabeth Anscombe and Harriet Baber, while avoiding the use of the traditional Aristotelian categories of substance and accidence, which are historically essential for the transubstantiation view of real presence.

The Catholic philosopher Elisabeth Anscombe states in her famous essay On transubstantiation that Eucharist is a strange ritual. ${ }^{\text {I If we }}$ think of, for example, washing the feet of our neighbors or eating together with them, these rituals are easy to understand. The obvious visible nature of the act and the meaning given to it are closely related. Washing the feet embodies the humility of the one doing the washing and the desire to serve others. Eating together is the most natural sign of the communion between persons. But what about eating and drinking someone's body and blood? This is the kind of language we use only if we intend to threaten our enemies, and even in that case the threat ("I shall drink your blood!") is truly extreme.

Anscombe goes on to ask under what kind of underlying assumptions the same words in a Christian prayer are not a violent threat, but an expression of the will of a deep communion. According to Anscombe, this requires really radical premises. For example, the person who is being eaten need to exceed all conventional features of a mere human person. The person in question needs to be divine and immortal. Subsequent philosophical models that attempt to make sense of the Eucharist must therefore be seen as attempts to explain this fundamental intuition behind the practice of the Eucharist. In sum, according to Anscombe, proper understanding of the ritual seems to require some kind real presence.

I E. Anscombe, On transubstantiation, in: Faith in a Hard Ground: Essays on Religion, Philosophy and Ethics, eds. M. Geach, L. Gormally, St. Andrews 2008, pp. 84-9I. 


\section{Three Basic Solutions}

In order to set a stage for my analysis, I propose the following basic distinction of different Eucharistic theologies. ${ }^{2}$ First of all, Christ's special or real presence can be denied altogether. There is no special change or presence in the physical elements of communion, but the change takes place (if it takes place) in the heart of the communicant, to whom Christ is presented as a commendable example. I understand that no major denomination or Church officially supports this model, although in practice individual members may think along these lines.

Second, the presence of Christ may be understood pneumatically. The change, in this case, concerns the specific reference relationship the bread and wine receive at the Communion table. The elements do not turn into the body and blood of Christ, but now they refer to Christ, who sits at the right hand of the Father. Christ's presence is however realized through the special presence of the Holy Spirit in the act of communion. ${ }^{3}$

In the real presence models, Christ's presence is understood as the real transformation of the elements: they become, in some real sense, the body and blood of Christ. These models can be divided into three parts: transubstantiation, consubstantiation, and impanation. In transubstantiation, the substances of the bread and wine turn into the body and blood of Christ, but the empirical features or the accidents of the elements are preserved. In consubstantiation, the substances of bread and wine do not change, but the body and blood of Christ become present alongside them as their own substances. In impanation, the form of Christ's presence in the Eucharist is understood as analogous to Christ's presence in the human person assumed through incarnation. Christ's body and blood permeate bread and wine as the divine nature of Christ permeates his human nature.

2 I follow here James Arcadi's exposition. See J.M. Arcadi, Recent Philosophical Work on the Doctrine of the Eucharist, "Philosophy Compass" II (2016) issue 7, pp. 402-4I2.

3 A recent sophisticated defense of the pneumatic model is N. Wolterstorff, The God We Worship. An Exploration of Liturgical Theology, Grand Rapids 2015. 
Lutherans, Catholics, Orthodox and some Anglicans understand the Eucharist so that Christ is truly present in it. ${ }^{4}$ Only Catholics have formulated a strict metaphysical theory of the nature of this presence. The Lutheran model is sometimes described through consubstantiation, but this is not a fully successful claim. Luther did not object transubstantiation because it somehow misrepresented Christ's presence, but because he thought that too restrictive philosophical category divisions were used to describe the manner of Christ's presence. Therefore, the consubstantiation would probably have been just as bad a description for Luther as transubstantiation. ${ }^{5}$ The impanation has not been widely supported, because it seems to lead to too corporeal form of Christ's presence: the communicant literally bites the body of Christ with her teeth. This would seem to be a violation of one of the essential ideas of real presence, namely that things that happen to bread and wine, do not actually happen to Christ. In other words, the communicant does not digest Christ in his stomach, nor does he get rid of the food in a way typical of digestion. ${ }^{6}$

\section{What Does Real Presence Require?}

Next, I approach communion from the point of view of what the Eucharist, understood in terms of real presence, seems to entail. Harriet Baber lists the following four points: ${ }^{7}$

4 For Lutheran Eucharistic theology, see Formula of Concord, Solid Declaration 7. The Catholic doctrine is presented in their Cathechism, see Catechism of the Catholic Church I373-I377, I4I3. For Orthodox theology, see A. Louth, Introducing Eastern Orthodox Theology, Downer's Grove 20I3, pp. IIo-II3.

5 For a Lutheran-Catholic ecumenical attempt to mutually understand the nature of Eucharist, see Communion in Growth. Declaration on the Church, Eucharist, and Ministry. Evangelical Lutheran Church in Finland. Catholic Church in Finland, Helsinki 2017 .

6 Impanation has recently been defended by Marilyn McCord Adams and James Arcadi. See M. McCord Adams, Some Later Medieval Theories of the Eucharist: Thomas Aquinas, Giles of Rome, Duns Scotus, and William Ockham. Oxford 2012; J.M. Arcadi, An Incarnational Model of the Eucharist, Cambridge 2018.

7 H.E. Baber, The real presence, "Religious Studies" 49 (2013) no. I, pp. I9-33. 


\section{DESIDERATA:}

(i) Theological realism: the doctrine that Christ is present in the Eucharist cannot be cashed out in terms of either claims about the psychological states of participants or theological claims about the transmission of grace or other benefits.

(ii) Empirical vacuity: as regards all physical characteristics and ordinary causal powers, the consecrated elements appear to be in every respect ordinary bread and wine.

(iii) Reference: the consecrated elements do not merely symbolize Christ: if someone were to point at them and say, 'That is Christ,' he would speak the literal truth.

(iv) Asymmetric dependence: the change in the elements at consecration depends (in some way) upon Christ but Christ himself is in no way affected by changes in the consecrated elements.

In my view, the principles put forward by Baber are a good illustration of what the real presence is supposed to affirm. ${ }^{8}$ On top of these, different metaphysical models can then be built to unite the above points. One example of this is transubstantiation, which, however, seems to be create difficult problems. According to Thomas Aquinas, two miraculous things happen in communion. ${ }^{9}$ First, Christ becomes present and changes the substance of bread. Secondly, the accidental properties, like taste, color and smell of the bread do not change. Consequently, the absence of bread and wine is actually a greater miracle than Christ's presence. The affirmation of transubstantiation therefore requires the adoption of a rather difficult and non-parsimonious philosophical view.

Baber herself proposes the following interpretation of real presence, which avoids the problems of the transubstantiation model. He thinks that the DESIDERATA can be structured with the help of following analogy. Let's imagine that I write a cheque. At the moment I write my name on a piece of paper (that is worthless as such) that paper

8 These are implicated in the standard expositions of Lutheran Eucharistic theology, see, e.g. M. Chemnitz, Lord's Supper, St. Louis 1979.

9 STh, Pars III q. 75-8I. 
will become worth of, say, Ioo euros. In other words, there is a real change in the value of the paper without there being a change in the substance of the paper as such. The value is not just a psychological state since the value of the cheque is independent of my (or anyone else's) beliefs, and even if someone doubts that the cheque is genuine, its authenticity does not suffer from this lack of belief. The cheque also looks like paper (and tastes like paper); its monetary value is not detected by senses. If someone points to a cheque with his finger and says, "That's roo euros," his proposition is true. Likewise, if someone burns a cheque, the cheque will be destroyed, but the money in my bank account is not decreased. Thus Baber's model fulfills the DESIDERATA.

Baber also offers another analogy of the ideas implicit in real presence, according to which all of Christ, not just a part of Christ, is present in a single piece of bread and drop of wine. This could be understood through the analogy of a broken mirror: each individual piece in the mirror reflects an entire image.

Baber admits that someone might consider the model described here to be too weak ontologically. Baber, however, thinks that if it is possible to linguistically express that $\mathrm{x}$ is $\mathrm{y}$ (this bread is the body of Christ), there is no need to give a stronger definition of presence. Still, one might ask whether this model is in fact a transsignification model? For example, James Arcadi suggests that there should be some stronger metaphysical basis behind real presence, that is, that there is something in the subjects themselves that allows them to be called the body and blood of Christ.

Joseph Ratzinger also denies that communion is just a language game or a kind of fiction..$^{\text {to }}$ According to Baber, however, not all games are "only" games. Ratzinger wants to resist reductionism in which the Eucharist would turn into some kind of pretense, where things would be real only in the sense analogous to kids' imaginative plays where objects represent absent things (e.g. "this tree is a pirate ship!") So how do you distinguish something being only a game, from something being more than just a game? We can imagine a game with real effects

Io Cf. J. Ratzinger, The presence of the Lord in the Sacrament, in God is Near Us: The Eucharist, the Heart of Life, eds. S.O. Horn, V. Pfnür, San Francisco 2003, pp. 74-93. 
on the world outside the game. For example, hockey is a game that can have a big impact even on the whole nation's psyche. ${ }^{\text {II }}$

\section{Real Presence and Relational Ontology}

Let me now turn to one possible interpretation of real presence, using relational ontology. ${ }^{\mathrm{I} 2}$ Relational ontology is usually understood as a counterpart to the constituent ontologies. Peter van Inwagen explains their difference like this:

A relational ontology is a polycategorial ontology (one of whose primary categories is "concrete particular" or something in the ontological neighborhood, something to very much the same ontological purpose: substance, individual, concrete thing...) that implies that concrete particulars have no ontological structure [...] According to any relational ontology, the only structure that concrete particulars have is good, oldfashioned everyday structure: mereological structure. A constituent ontology, like a relational ontology, includes "concrete particular" in its inventory of ontological categories. But, unlike relational ontologies, constituent ontologies imply that concrete particulars have an ontological structure: they have constituents (perhaps parts in the strict sense, perhaps not) that do not belong to the category "concrete particular. ${ }^{13}$

According to relational ontology, individual things do not have such an ontological structure. Instead, their structure consists of parts of things and relations between them. For example, a dog's structure is something, that supervenes a state of affairs in which certain parts, or "stuff" and their mutual relationships are organized "dog-like" at a given moment. Relational ontology does not deny that there are things or other individual essences. Instead, it merely argues that they

II As in Finland in 1995, when Finland beat Sweden in the final of ice hockey world championships.

I2 P. van Inwagen, Relational vs. Constituent Ontologies, "Philosophical Perspectives” 25 (20II), pp. 389-405; See also R.C. Koons, T.H. Pickavance, Metaphysics: The Fundamentals, Oxford 2015, pp. I05-IIo; R.C. Koons, T.H. Pickavance, The Atlas of Reality: A Comprehensice Guide to Metaphysics, Oxford 2017, pp. I78-179.

I3 P. van Inwagen, Relational vs. Constituent Ontologies, op. cit., pp. 390-39I. 
can be defined without having to claim that certain elements form a constituent relationship with one another. ${ }^{14}$

For example, "a red ball" is an object or state of affairs in which REDNESS and ROUNDNESS are instantiated. A proponent of relational ontology strives for the simplest possible metaphysics, with as few explanatory factors as possible..$^{15}$ However, there are some things in relational ontology that go against our everyday intuition, such as the absence of chairs or tables, even though there are cases in which matter is sometimes organized, for example, in a form that we call a chair or table. Nonetheless, on relational ontology, we would be unable to say that things have intrinsic properties, because they only receive their properties when they are related with other properties in a suitable manner at the right moment.

If we entertain the possibility that relational ontology is a good general ontology (which I have not argued for here), we could think that the consecrated elements are the body and blood of Christ when in them BREAD, WINE, and CHRIST are instantiated. This metaphysical definition meets Anscombe's and Baber's desiderata, and it does not require answering the difficult questions that appear to bother transubstantiation. Christ can be present as a divine person anywhere he wants, and correspondingly the absence of the substances of the bread and wine need not be explained. ${ }^{16}$ From the Lutheran point of view, what is present in the elements is the person of Christ, which has two natures, human and divine. Through the communication of attributes (communication idiomatum), the natures share each other's properties so that one person is being formed as a result.

I4 Why endorse this view in the first place? According to Van Inwagen, relational ontology is simpler and more explanatory than competing theories, because it does not require answering difficult questions, such as, what constitution is and how things form constituent relationships.

I5 I admit that a constituent ontologist would argue she is striving to the same end with her theory. In this essay, I will conveniently avoid the question concerning which metaphysical grand system is the most parsimonious in the end.

i6 It should also be noted that the model is also capable to adhering to the doctrine of manducatio impiorum, according to which also unworthy recipients eat and drink the body and blood of Christ. This doctrine was considered a litmus test for the real presence in early Lutheran circles. See, M. Chemnitz, Lord's Supper, op. cit., pp. I27-I3I. 
However, the real presence interpreted in accordance with relational ontology requires the acceptance of two controversial theses. First of all, it requires us to have some good reasons to embrace relational ontology as a basic metaphysical theory. Relational ontology is not a universally accepted theory, but this applies to all other theories as well. It can therefore be regarded as one possible and rational theory that describes well at least some aspects of the nature of reality. However, if one adopts relational ontology understood as van Inwagen does, that would require one to apply it to other relevant doctrines as well, which I have not argued for here.

Secondly, relational ontology requires that Christ's natures should be interpreted as abstract, not concrete, natures. For the interpretation presented here to be coherent, the body of Christ and the body of Christ must be understood as something more akin to universals, not concrete particulars. In other words, what we call the person of Christ that consists of two natures is a loose collection of certain qualities and properties, the association of which creates the states of affairs we call "nature" and "person."

Many historical and contemporary interpretations of the natures of Christ are abstract, so this, too, is not an insurmountable obstacle. In my view, relational ontology offers one possibility of presenting a Lutheran theology of Eucharist in a theoretical form, if only these two conditions are accepted. Moreover, the relational ontology would enable Catholics to express their idea of the real presence without resorting to the categories of substance and accidence. ${ }^{18}$

I7 I think that it would be possible the say that Christ during his earthly life could have been interpreted as a concrete particular, that is, as a singular thing. However, after ascension and seen through communicatio idiomatum, this does not seem to be an apt category. Now Christ becomes something that is sui generis, and we lose to a great extent the grasp how certain words and concepts apply to him. This is apparent in the conceptual problems the communication idiomatum doctrine itself faces. I take this not as a reason reject the doctrine but as something that signals that we are approaching the borderline where human language is not enough anymore in describing things that are transcendent.

I8 A Finnish version of this article has been previously published in my collection of essays Ä̈riviivoja: esseitä kristillisen dogmatiikan ydinkobdista, Helsinki 2020. Republished with permission. 


\section{BiBLIOGRAPHY}

Anscombe E., On transubstantiation, in Faith in a Hard Ground: Essays on Religion, Philosophy and Ethics, eds. M. Geach, L. Gormally, St. Andrews 2008, pp. 84-9i.

Arcadi J.M., An Incarnational Model of the Eucharist, Cambridge 2018.

Arcadi J.M., Recent Philosophical Work on the Doctrine of the Eucharist, "Philosophy Compass" II (2016) issue 7, pp. 402-4I2.

Baber H.E., The real presence, "Religious Studies" 49 (2013) no. I, pp. 19-33.

Communion in Growth. Declaration on the Church, Eucharist, and Ministry. Evangelical Lutheran Church in Finland, Catholic Church in Finland, Helsinki 20I7.

Chemnitz M., Lord's Supper, St. Louis 1979.

Inwagen P. van, Relational vs. Constituent Ontologies, "Philosophical Perspectives" 25 (20II), pp. 389-405.

Koons R.C., Pickavance T.H., The Atlas of Reality: A Comprehensice Guide to Metaphysics, Oxford 2017.

Koons R.C., Pickavance T.H., Metaphysics: The Fundamentals, Oxford 2015.

Louth A., Introducing Eastern Orthodox Theology, Downer's Grove 20I3.

McCord Adams M., Some Later Medieval Theories of the Eucharist: Thomas Aquinas, Giles of Rome, Duns Scotus, and William Ockham, Oxford 2012.

Ratzinger J., The presence of the Lord in the Sacrament, in: God is Near Us: The Eucharist, the Heart of Life, eds. S.O. Horn, V. Pfnür, San Francisco 2003, pp. 74-93.

Wolterstorff N., The God We Worship. An Exploration of Liturgical Theology, Grand Rapids 2015. 